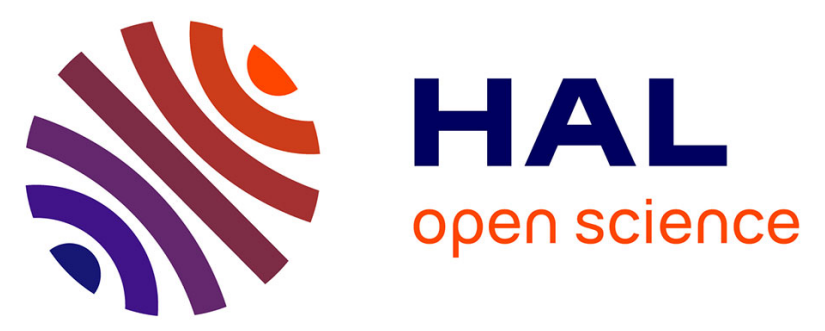

\title{
Varietal mixture of poplar clones: effects on infection by Melampsora larici-populina and on plant growth
}

\author{
S. Miot, Pascal Frey, Jean Pinon
}

\section{To cite this version:}

S. Miot, Pascal Frey, Jean Pinon. Varietal mixture of poplar clones: effects on infection by Melampsora larici-populina and on plant growth. European Journal of Forest Pathology, 1999, 29, pp.411-423. hal-02691618

\section{HAL Id: hal-02691618 \\ https://hal.inrae.fr/hal-02691618}

Submitted on 1 Jun 2020

HAL is a multi-disciplinary open access archive for the deposit and dissemination of scientific research documents, whether they are published or not. The documents may come from teaching and research institutions in France or abroad, or from public or private research centers.
L'archive ouverte pluridisciplinaire HAL, est destinée au dépôt et à la diffusion de documents scientifiques de niveau recherche, publiés ou non, émanant des établissements d'enseignement et de recherche français ou étrangers, des laboratoires publics ou privés. 


\title{
Varietal mixture of poplar clones: Effects on infection by Melampsora larici-populina and on plant growth
}

\author{
By S. Miot, P. FreY and J. PinON ${ }^{1}$ \\ Pathologie Forestière (Ecosystèmes forestiers). Institut National de Recherche Agronomique. 54280 \\ Champenoux, France ('for correspondence)
}

\begin{abstract}
Summary
The effects of poplar varietal mixture on infection levels caused by Melampsora larici-populina and on plant growth were studied during two consecutive growing seasons. The varietal mixture consisted of an intimate mixture of three poplar clones, Populus $x$ interamericana 'Boelare', 'Rap' and Populus candicans 'NNT', expressing different race-specific resistances. Infection levels of $M$. larici-populina were assessed in monoclonal and polyclonal plots. Plant heights were determined at the end of each growing season. Infection levels in the growing season of the first year were not significantly different between monoclonal and polyclonal plots at the end of the epidemic. During the second growing season, a naturally occurring complex pathotype, able to infect clones 'Boelare' and 'Rap', invaded some plots prematurely and changed the composition of pathogen population. During this season, four infection assessments were conducted. Infection reduction in polyclonal plots compared with monoclonal plots was observed on 'Boelare' and $P$. candicans plants. Nevertheless, no significant difference was observed for growth between monoclonal and polyclonal plots. Biological factors which may be involved in the reduction of infection levels in polyclonal plots are dilution of susceptible individuals, physical barriers caused by resistant plants and cross-protection. A high auto-infection ratio may have partly hidden the positive effects of the clonal mixture.
\end{abstract}

\section{Introduction}

Poplar is one of the major forest trees that is used for wood production in France with 244000 ha of plantations and an annual wood harvest of 2.6 million $\mathrm{m}^{3}$ in 1994 (SCEES 1996). Poplar is used essentially in sawing and peeling industries (SALES 1995). At present, as many as 130 poplar clones, selected for wood quality, environmental adaptation and pest resistance, can be planted throughout all of the European Union countries (TERRASSON and VALADON 1993). In spite of this, poplar plantations are generally composed of a very limited number of clones: mainly Populus $x$ euramericana (Dode) Guinier and Populus $x$ interamericana Brockh. F1 clones (PINON 1995; VIART 1998). For example, poplar plantations in Northern France consist of $80 \%$ of $P . x$ interamericana 'Beaupré' (PINON et al. 1998).

This low genetic diversity associated with monoculture practice may have contributed to the degradation of poplar health over the past decades due to biotic aggressions by fungi, bacteria and insects (HEYBROEK 1978, 1982a; VIART 1998). Among poplar diseases, increasing damage due to leaf rusts is particularly alarming (PINON et al. 1987; PINON et al. 1998). Melampsora larici-populina Kleb. is a foliar obligate parasite which causes premature defoliation, shoot and root growth reduction (SPIERS 1976; STEPIEN 1992). Melampsora larici-populina epidemics, followed by infection with secondary parasites such as Cytospora chrysosperma (Pers.) and Discosporium populeum Sacc. (Sutton), can cause critical economic loss and even plant death (SPIERS 1976; DE KAM 1983). 
Furthermore, cultivation of poplar clones with race-specific resistance to M. larici-populina has induced modifications in the pathotype populations of the fungus. Consequently, eight virulences have been described and, at present, none of the poplar clones registered in the European Union remains completely resistant to this parasite (PINON 1995; PINON et al. 1998).

In response to this worrying situation, poplar breeders have to develop new breeding programmes in order to select for more durable resistance (VIART 1998). To reduce parasite epidemics and to increase poplar plantation diversity, the management of the spatial distribution of cultivars has been also suggested (HEYBROEK 1982a; VIART 1998). In order to increase genetic diversity at the national and regional scale, HEYBROEK (1982b) suggested the plantation of a mosaic of monoclonal plots comprising a large number of clones. VIART (1998) and PARKER et al. (1996) proposed alternate row plantations of different clones, to reduce parasite progression and rapid selection of complex pathotypes. 'Synthetic multiclonal hybrid varieties' were suggested by SCHREINER (1966) to reduce epidemiological risks. They consist of poplar clone mixtures with different resistances to one or more parasites and with similar growth requirements. Up to now, no benefits of varietal mixtures of poplar clones have been shown in terms of growth parameters (BISOFFI 1992; DEBELL and HARRINGTON 1997). The latter studies did not take plant health into account, which is a major concern for poplar cultivation.

Many studies on cereals have demonstrated the benefits of varietal mixture in controlling plant disease epidemics (BERGER 1972; WHITE 1982; FINCKH and MUNDT 1992) associated, in some cases, with increasing yields (JENSEN 1952; MAHMOOD et al. 1991; FINCKH and MUNDT 1992).

Infection reduction in mixed stands compared to monoclonal stands results from interactions between several factors (BURDON 1978; WOLFE et al. 1981): (i) dilution of susceptible individuals reduces the amount of susceptible tissues and this in turn reduces the quantity of inoculum in the plot (LEONARD 1969; CHIN and WOLFE 1984; AKANDA and MUNDT 1996); (ii) resistant individuals create a physical barrier which limits the spread of inoculum between susceptible plants and delays the onset of the disease (BURDON 1978; CHIN and WOLFE 1984; WOLFE 1985); (iii) other mechanisms such as cross-protection and competition between pathotypes of the parasite can contribute to infection reduction (LEONARD 1969; Johnson and Allen 1975; Chin and Wolfe 1984; CAlOnNeC et al. 1996).

Until now, there have been few examples of varietal mixtures for woody plants. Clonal mixtures of willow, planted in short-rotation coppice, delayed the onset of rust epidemics caused by Melampsora epitea var. epitea Thüm., slowed its build-up and resulted in a lower disease level at the end of the growing season, in comparison with monoclonal stands (MCCRACKEN and DAWSON 1994, 1997). Computer-simulated epidemics of apple scab, caused by Venturia inaequalis (Cooke) Winter, in mixed apple orchards suggested a relationship between the increase of cultivar mixture complexity and the disease reduction (BLAISE and GESSLER 1994). Varietal mixtures have also been successfully used in order to control coffee rust epidemics, caused by Hemilia vastatrix Berk. and Br. 'Variedad Colombia', which covered about 300000 ha in Colombia, is a multiclonal coffee variety, composed of about $44 \mathrm{~F}_{6}$ progenies selected for similar agronomic characteristics and differences in rust resistance (MORENO-Ruiz and CASTILlO-ZAPATA 1990; J. A. Browning, personal communication).

Mixed poplar stands may be a way of increasing diversity and may limit rust epidemics caused by M. larici-populina. The aim of this study was to test, for the first time, the effects of a poplar clone mixture on rust infection severity and on plant growth, in comparison with monoclonal plots. The varietal mixture was composed of three poplar clones expressing the three economically important race-specific resistances to $M$. larici-populina, which have been overcome recently (PINON 1995). Assessments of infection level and plant height were carried out during two consecutive growing seasons. 


\section{Materials and methods}

\subsection{Experimental design}

The field trial was composed of monoclonal and polyclonal plots. It was localized in the north-east of France near Nancy which is not an area of poplar plantation. This trial was established in a clearing located in the middle of a forest composed mainly of oaks and some aspen trees in order to limit external contamination by M. larici-populina. The closest poplars were those from the experimental nursery of INRA, $2.2 \mathrm{~km}$ north and separated from the trial by an area of forest that is $900 \mathrm{~m}$ wide. The field trial was planted in April 1997 with cuttings obtained during spring 1997. Three poplar clones expressing different race-specific resistances to $M$. larici-populina were chosen according to their adaptation to the soil characteristics of the site. Populus candicans 'NNT', P. $x$ interamericana 'Rap' and $P$. $x$ interamericana 'Boelare' are susceptible to $M$. larici-populina pathotypes exhibiting at least virulence 2, 5 and 7, respectively (PINON 1995).

The experimental design consisted of four randomized complete blocks, each with four plots (three monoclonal plots and one polyclonal plot) $2.8 \mathrm{~m}$ wide (three rows) and $4 \mathrm{~m}$ long (six columns). Monoclonal plots were composed of 18 cuttings of one clone, whereas polyclonal plots contained six cuttings of each clone. The cuttings in polyclonal plots were displayed in order to avoid neighbouring between two consecutive cuttings from the same clone in a row and in a column. Each plot was separated from the next plot by three columns of Populus trichocarpa Torr. and Gray 'Fritzi-Pauley' cuttings, a clone weakly susceptible to all M. larici-populina pathotypes. Borders were also planted with this clone in order to reduce external contamination.

\subsection{Initiation of infection in the trial}

Since natural infections in poplar stands usually occur from July to mid-August, artificial focal infections were initiated on 18 July 1997 and 21 July 1998 in each experimental plot. Three monouredinial isolates of $M$. larici-populina, belonging to pathotypes 2-3-4, 1-3-45 and 3-4-7, which are virulent on clones $P$. candicans, 'Rap' and 'Boelare', respectively, were chosen for the study. Each isolate originally derived from a single uredium isolated from a weakly infected poplar leaf. They were characterized for their pathotype and multiplied on P. x euramericana 'Robusta' leaves under laboratory-controlled conditions as previously described by PINON et al. (1987). Three-month-old 'Robusta' plants, a clone that is highly susceptible to all $M$. larici-populina pathotypes, were inoculated in the laboratory. A suspension of urediniospores $(10000$ urediniospores $/ \mathrm{ml})$ in water agar $(0.1 \mathrm{~g} / \mathrm{l})$ of each isolate was sprayed onto the lower face of the leaves numbered 6-11 from the apex of eight 'Robusta' plants. Inoculated plants were maintained in a growth chamber under the controlled conditions $\left(70 \%\right.$ relative humidity, $18 \mathrm{~h}$ day at $22^{\circ} \mathrm{C}$ and $6 \mathrm{~h}$ night at $18^{\circ} \mathrm{C}$ ). Uredia appeared after 8 days. Infected 'Robusta' plants were then taken to the experimental site. One 'Robusta' plant previously inoculated with a compatible isolate was introduced into each monoclonal plot, whereas three 'Robusta' plants, each inoculated with one of the three isolates, were introduced in each polyclonal plot.

\subsection{Disease assessment}

In 1997, only one disease assessment was carried out on the 17 September. In 1998, five disease assessments were carried out, between July and September. Infection assessments were carried out on one shoot of the current year per plant by evaluating the number of uredia on each leaf according to a four-class scale: class $1=$ no uredia; class $2=1-10$ uredia; class $3=11-100$ uredia; class $4=$ more than 100 uredia. 
In order to transform these discontinuous values to continuous values, the method previously described by JOANNES and PINON (1982) was applied. A correspondence analysis (CA) was performed on the percentage of leaves in each class for each shoot. The CA permitted to obtain a coefficient corresponding to the respective ordinate of each class on the first factorial axis. An infection score for each shoot was obtained by multiplying the percentage of leaves in each class by the respective coefficient determined by the CA. These infection scores were then transformed to obtain notes from 0 to 100.

\subsection{Identification of pathotypes}

In 1998, identification of pathotypes was carried out in the laboratory, at the end of epidemic, on samples from plots prematurely infected by naturally occurring pathotypes of M. larici-populina. Since the predominant pathotype was identified as a complex pathotype 1-3-4-5-7, pathotype identifications were carried out in order to evaluate the relative abundance of this complex pathotype on 'Boelare' and 'Rap' leaves. About 30 to 40 leaves from 'Boelare' and 'Rap' plants were sampled in October in monoclonal and polyclonal plots of blocks 3 and 4, respectively. Pathotype identification was carried out on a sample of 100 uredia of $M$. larici-populina from each experimental plot. Each selected uredium was inoculated onto $12 \mathrm{~mm}$ diameter leaf discs of a differential set of eight poplar clones, as previously described by PINON and FREY (1997). Leaf discs were incubated by floating them on water in 24-well plates, abaxial surface uppermost, at $20^{\circ} \mathrm{C}$ under continuous illumination (fluorescent light, $25 \mu \mathrm{mol} / \mathrm{s} \mathrm{m}^{2}$ ). During the 2 weeks following the inoculation, the discs were observed daily to detect the formation of uredia in the case of compatibility.

\subsection{Plant height}

The height of each plant was measured at the end of the growing season, in October 1997 and October 1998, in order to test the effect of varietal mixture on growth.

\subsection{Statistical analysis}

Infection scores were analysed by variance analysis using procedure GLM from Statistical Analysis Software (SAS INSTITUTE INC. 1989). For some assessment dates, the graph of residual values by predicted values indicated a nonhomogeneous distribution of residuals. Data were transformed to obtain a normal distribution of residuals. For each date, clone and plot type (monoclonal or polyclonal) were introduced as fixed effects. Block factor was considered as a random effect. The distance between any infected plant and the inoculated 'Robusta' plant in each plot, was introduced as a covariable.

Plant growth in 1998 corresponding to the difference between the height in 1998 and height in 1997 was analysed by SAS procedure GLM. Data were square transformed to obtain a normal distribution of residuals. Clone and plot type were introduced as fixed effects and block factor as a random effect. Linear regression analysis was performed using the SAS procedure REG, in order to study the relationship between plant growth in 1998 and plant infection in 1997. 


\section{Results}

\subsection{Disease assessment in 1997}

No natural infections were detected before the introduction of the inoculated 'Robusta' plants. Artificial focal infections rapidly developed in each plot, starting from the plants located near the inoculated 'Robusta' plants. Infection assessments were carried out, before leaf fall, on 17 September 1997. The infection level was not significantly different between blocks $(p>0.05)$. Altogether, disease severity in polyclonal plots $(52 \%)$ was not significantly different $(\mathrm{p}>0.05)$ from that of monoclonal plots $(50 \%)$. The effects of the mixture on the infection level interacted significantly with the clone factor $(\mathrm{p}<0.05)$. Surprisingly, $P$. candicans was significantly more infected in polyclonal plots $(72 \%)$ compared with monoclonal plots (61\%) (Fig. 1). For 'Boelare' and 'Rap' no significant difference was observed in the infection level between polyclonal and monoclonal plots (Fig. 1). Infection level depended on the clone $(\mathrm{p}<0.001)$. Overall, $P$. candicans was significantly more infected $(67 \%)$ than 'Boelare' (53\%) and 'Rap' (34\%).

The distance covariable was significant $(\mathrm{p}<0.001)$. This covariable reflected the distribution of infection intensity in the plot. A decreasing infection gradient from the initial infection point was observed in many plots (data not shown).

\subsection{Disease assessment in 1998}

Since, early natural infections occurred in some plots, an infection assessment was carried out, on 16 July 1998, before the introduction of the inoculated 'Robusta' plants. Indeed, infection scores were 5 and $17 \%$ in monoclonal 'Boelare' plots and 0.3 and $0.8 \%$ on 'Boelare' plants in polyclonal plots in block 2 and 4, respectively. Infection score was $12 \%$ in monoclonal 'Rap' plot whereas it was $0.6 \%$ in polyclonal 'Rap' plot of block 3 . The natural contaminations began on some plants within these monoclonal plots and may have induced multifocal infections. The monoclonal plots were the most infected whatever the assessment date and these early infections were shown to be mainly due to a naturally occurring pathotype 1-3-4-5-7. At the end of the epidemic, the frequency of this complex pathotype

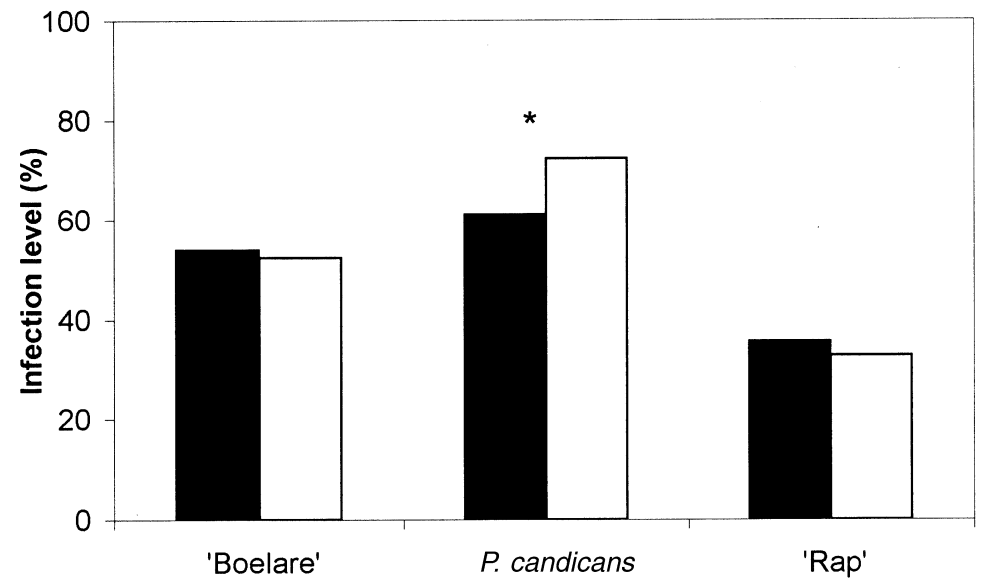

Fig. 1. Infection levels on 17 September 1997 on 'Boelare', P. candicans and 'Rap' plants in monoclonal (black) and polyclonal plots (white). An asterisk denotes a significant difference $(\mathrm{p}<0.05)$ within a clone between infection level means in polyclonal and monoclonal plots 

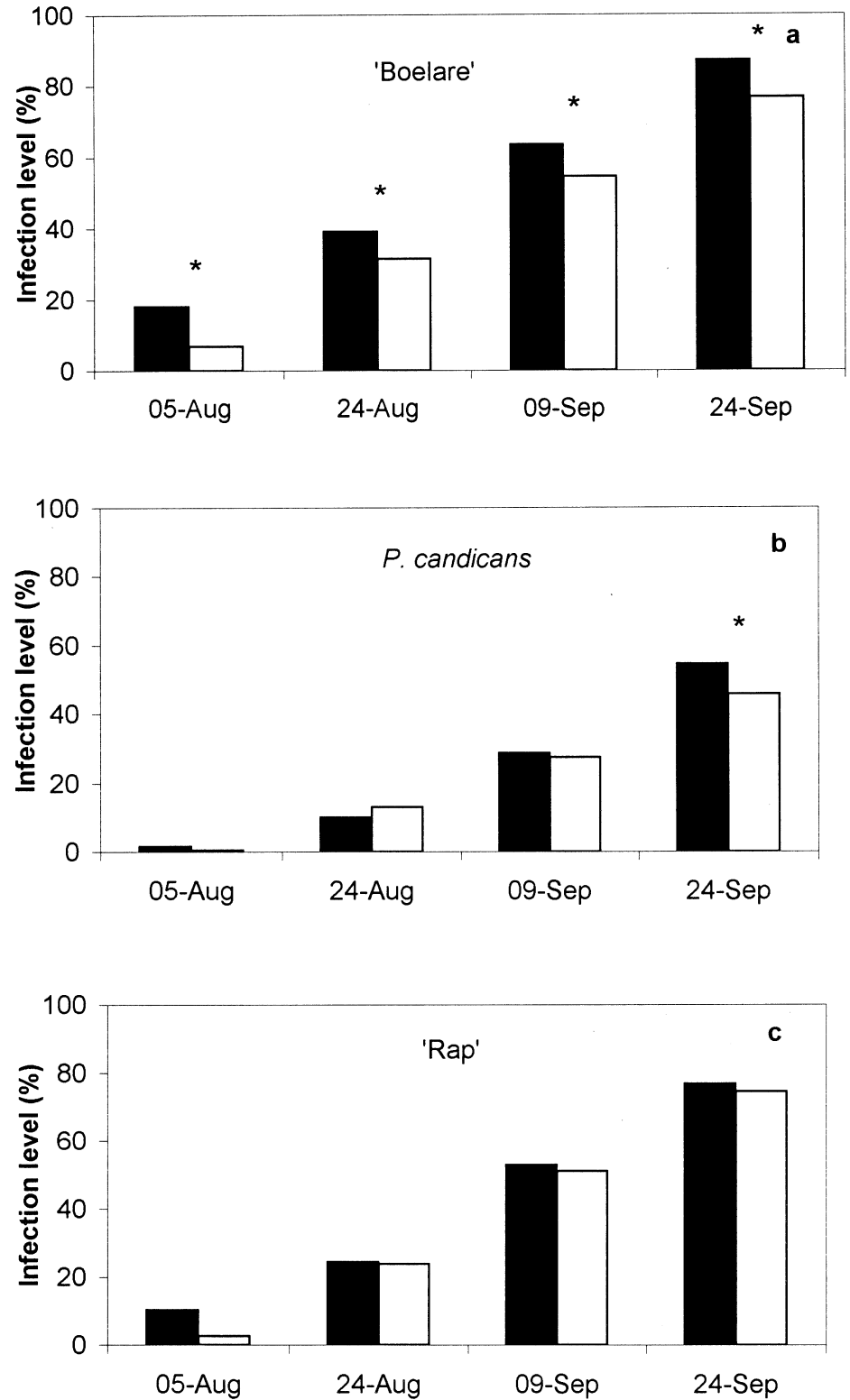

Fig. 2. Infection levels on 'Boelare' (a), P. candicans (b) and 'Rap' (c) plants for each assessment date during summer 1998 in monoclonal plots (black) and polyclonal plots (white). Significantly different values $(\mathrm{p}<0.05)$ are indicated by an asterisk

was $97 \%$ on 'Rap' plants in the monoclonal and polyclonal plots of block 3 and $50 \%$ on 'Boelare' plants in polyclonal plots of block 4. However, the pathotype 3-4-7 was the most frequent in the 'Boelare' monoclonal plot in block 4. 
After the introduction of the inoculated 'Robusta' plants, four infection assessments were carried out during summer 1998 in order to describe the evolution of infection in the trial.

The effects of the mixture on the level of $M$. larici-populina infection, at all notation dates, varied with block and clone factors $(\mathrm{p}<0.05)$.

During the first three infection assessments ( 5 and 24 August and 9 September) the results were almost similar. 'Boelare' plants were significantly more infected in monoclonal plots than in polyclonal plots $(\mathrm{p}<0.05)$ (Fig. $2 \mathrm{a})$. The infection reduction on 'Boelare' plants was about 11,8 and $10 \%$, at the three assessment dates, respectively. Infection scores on $P$. candicans and 'Rap' plants were not significantly different between monoclonal and polyclonal plots during these three assessment dates (Fig. 2b,c). Infection levels varied with the clones ( $\mathrm{p}<0.001)$. 'Boelare' was significantly more infected than 'Rap' and $P$. candicans.

On the fourth assessment date (24 September), 'Boelare' and $P$. candicans were significantly more infected in monoclonal plots compared with polyclonal plots $(\mathrm{p}<0.05)$ (Fig. 2a, b). Disease reductions between polyclonal and monoclonal plots were $10 \%$ on 'Boelare' plants and $8 \%$ on $P$. candicans plants. Infection means of 'Rap' plants were not significantly different in monoclonal and polyclonal plots (Fig. 2c). Infection levels varied significantly with clones $(\mathrm{p}<0.001)$. The difference between infection levels on 'Boelare' $(82 \%)$ and 'Rap' $(79 \%)$ was reduced at the end of the epidemic. Populus candicans was less infected (49\%). This latter clone had a higher infection level in blocks 3 and 4 (data not shown).

From the end of August, the distance covariable explained a part of the variability of infection intensity $(\mathrm{p}<0.001)$. This variable represented the heterogeneity of infection in plots due to focal infections.

\subsection{Plant growth}

At the end of the 1998 growing season, the mean heights of 'Boelare', 'Rap' and P. candicans plants were 2.5, 2.3 and $1.0 \mathrm{~m}$, respectively. Mean plant growth in 1998, corresponding to the difference between plant height in 1997 and 1998, was not significantly different between monoclonal and polyclonal plots $(\mathrm{p}>0.05)$. Nevertheless, plant growth of 'Boelare' and $P$. candicans in 1998 was slightly higher in monoclonal plots compared with that in polyclonal plots but the differences were not significant (Fig. 3). The variability of plant growth in 1998 depended on block $(\mathrm{p}<0.001)$ and clone factors $(\mathrm{p}<0.001)$. The mean growth of

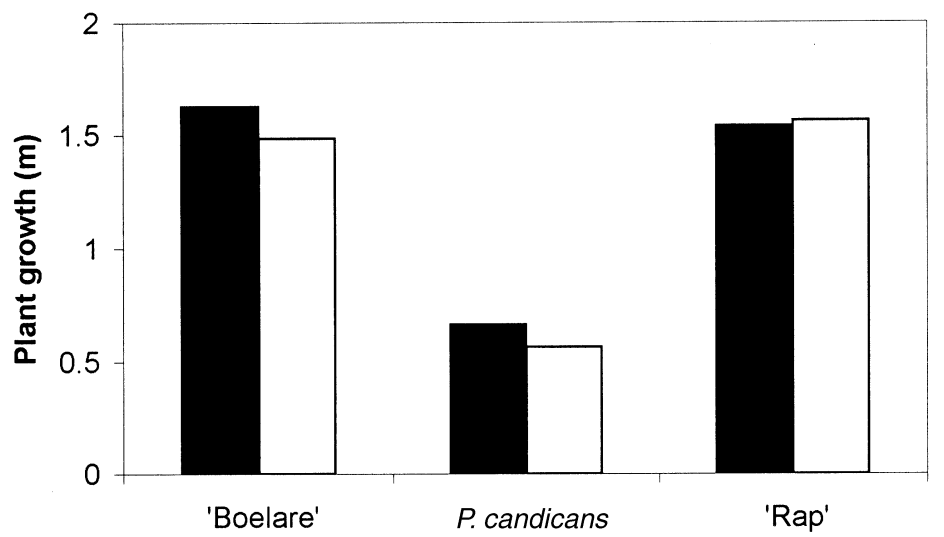

Fig. 3. Comparison of growth of 'Boelare', $P$. candicans and 'Rap' plants in monoclonal (black) and polyclonal (white) plots 
'Boelare' and 'Rap' plants in 1998 was the same $(1.5 \mathrm{~m})$. Their growth was significantly greater than that of $P$. candicans plants $(0.6 \mathrm{~m})$ (Fig. 3). Whatever the clone, plants from blocks 1 and 2 were significantly taller than plants from blocks 3 and 4 . The soil in blocks 3 and 4 had a higher water content and may have caused root asphyxia which limited plant growth. Plant growth in 1998 was negatively correlated with the infection level in 1997 $\left(\mathrm{p}=0.0001, R^{2}=0.096\right)$. The regression equation was: plant growth in $1998=172-0.89 \times$ (infection score in 1997).

\section{Discussion}

\subsection{Infection score}

The overall infection levels on poplar clones were variable during the two growing seasons. This variability might be associated with growth of the plant crowns which created a humid microclimate more favourable to rust infection in 1998 than in 1997 and also to the multiplication of naturally occurring pathotypes on 'Boelare' and 'Rap' plants. Consequently, 'Boelare' and 'Rap' plants were more infected at the end of the epidemic in 1998 compared with 1997. Populus candicans plants were equally infected in monoclonal plots during the 2 years and less infected in polyclonal plots in 1998 compared with 1997.

This first study on a poplar clone mixture revealed variability in the effects of mixture on $M$. larici-populina infection during two consecutive growth seasons. Variability in the effects of varietal mixtures has also been observed between years and between sites for cereals (WhiTe 1982; FINCKH and MUNDT 1992) and willows (MCCRACKEN and DAwSON 1994). In the present study, at the end of the first growing season, the mean infection in polyclonal plots was not significantly different from the mean infection of monoclonal plots. Furthermore, infection on $P$. candicans was significantly higher in mixture plots compared with monoclonal plots. Taller plants of 'Boelare' and 'Rap' in mixture plots could have created a humid microclimate, which might have caused more infections on the smaller $P$. candicans plants. During the second growing season, infection reduction in mixture plots was clonedependent. Infection level was significantly reduced in polyclonal plots compared with monoclonal plots, on 'Boelare' plants at all assessment dates, and on P. candicans plants at the end of epidemic. The variability of mixture effects during the two growing seasons could be associated with the modification in the M. larici-populina population, due to the presence of naturally occurring pathotypes, including the complex pathotype 1-3-4-5-7. The difference in the mean infection levels between polyclonal and monoclonal plots in 1998 on 'Boelare' plants in mixture plots compared with monoclonal plots could be attributed to a great extent to the delayed onset of natural infections. Indeed, this naturally occurring inoculum appeared quite early in the season in monoclonal plots of 'Boelare' of blocks 2 and 4 which had the best mean height in 1997 and may thus have acted as spore traps. Consequently, infection scores were more important in these plots, on $16 \mathrm{July}$, before the introduction of the inoculated 'Robusta' plants. Then, the rapid spread of inoculum may have been favoured in monoclonal plots and resulted in a higher infection in monoclonal plots compared with mixtures during all the evolution of epidemic.

Infection reduction in varietal mixtures could be attributed to several parameters as evoked in the introduction. Dilution of susceptible individuals is an essential parameter involved in infection decrease in cereal mixtures (LEONARD 1969; CHIN and WOLFE 1984; AKANDA and MUNDT 1996). A mixture of equal proportions of two wheat varieties was the best strategy to decrease infection caused by Puccinia striiformis Westend pathotypes, compared with pure stands (AKANDA and MUNDT 1996). A random mixture of wheat varieties was shown to be the disposition which created the best dilution of susceptible individuals, and thus contributed to an increase in mixture efficiency (MUNDT et al. 1996). Our poplar mixture consisted of an intimate mixture where plants were disposed in order 
to avoid neighbouring, in column or row, between plants of the same clone. One-third of the plants in the mixture plots was susceptible to only one of the three inoculated M. laricipopulina pathotypes. However, in 1998, two-thirds of the plants in mixture plots, 'Boelare' and 'Rap' plants, were susceptible to the naturally occurring complex pathotype 1-3-4-57. In the two blocks chosen for pathotype screening, this pathotype was abundant in both the monoclonal and polyclonal plots at the end of the epidemic. On 'Rap' plants in block 3 it was predominating and on 'Boelare' plants in the polyclonal plot of block 4 it accounted for $50 \%$ of the inoculum. Therefore mixture efficiency may have been reduced because of an increase in the proportions of susceptible individuals in mixture plots. Resistant plants act as physical barriers in a mixture. Consequently, they reduce the spread of inoculum and induce the loss of propagules (BURDON 1978). Due to the presence of taller plants in 1998, the physical barrier may have played a more important role than in 1997, at least at the beginning of the epidemic. Nevertheless, no significant differences in infection level were observed on 'Rap' and $P$. candicans plants between monoclonal and polyclonal plots at the beginning of the epidemic. It is likely that dilution and physical barrier factors may have played a minor role in our trial due to the small size of the plots and the small number of clones in the mixture.

Cross-protection by avirulent pathotypes was also described as an important factor which could reduce the infection level in cereal mixtures. One-third of the infection decrease, in wheat polyclonal plots, was attributable to induced resistance (CALONNEC et al. 1996). Experiments in laboratory conditions are in progress in order to evaluate the actual role of cross-protection on the three poplar clones. Cross-protection by incompatible pathotypes was shown to be effective on 'Boelare' and $P$. candicans leaf discs, but conversely not on 'Rap' leaf discs (MIOT 1999). These results suggest that cross-protection could occur in the field and may be dependent on the clone. Furthermore, in the field trial the effects of crossprotection may be cumulative over several infection cycles. Consequently, the decrease in disease severity in poplar mixtures attributable to cross-protection may be greater at the end of the epidemic. Thus, the reduction of infection in polyclonal plots of $P$. candicans at the end of September 1998 could be attributable to cross-protection induced by incompatible pathotypes. At the end of an epidemic in barley mixtures, the effects of cross-protection predominated on the two other factors involved in the decrease of infection caused by Erysiphe graminis DC. f. sp. hordei Marchal (CHIN and WOLFE 1984).

Nevertheless, the effects of these three biological factors might be partly hidden also by a high auto-infection ratio. Indeed, mixture efficiency depends on the allo-infection/autoinfection ratio, which varies with the area covered by a genotype unit and with the steepness of the dispersal gradient of the pathogen (MUNDT and LEONARD 1986; LANNOU and MUNDT 1996). In the case of perennial woody plants, the area covered by each susceptible individual is much larger than in the case of a cereal. Therefore, when a M. larici-populina urediniospore reaches a susceptible poplar leaf, it is surrounded by many susceptible leaves (Heybroek 1978, 1982b). Asexual reproduction in a poplar crown is sufficient to initiate an epidemic and thus reduces the allo-infection/auto-infection ratio. Therefore the large area of each susceptible genotype unit, acting as an own plot-unit with its high leaf mass present, may reduce the efficiency of poplar clone mixtures. In cereal crops, increasing the number of tillers was correlated with the increase in auto-infection during a growth season (CHIN and WOLFE 1984).

\subsection{Plant growth}

Mean growth in 1998 was not significantly different between polyclonal and monoclonal plots. A slight, but not significant, growth increase was also observed in mosaic monoclonal plots of P. x euramericana or Populus deltoides clones compared with polyclonal plots (BISOFFI 1992). The mean yield of four poplar clones in mixed plantations did not differ 
significantly from that of monoclonal plots of the same clones (DEBELL and HARRINGTON 1997). These results did not take into account possible infections by fungi.

In varietal mixtures, interactions between different genotypes may influence the yield in different ways. Three types of interactions have been described in the literature: (i) complementation, which results in a mixture yield greater than the sum of the components planted in monoculture; (ii) compensation, in which the reduced growth of a clone more susceptible to biotic or abiotic factors is compensated by an increased growth of another less susceptible clone; and (iii) competition, which results in yield decrease due to negative interactions between components of the mixture (ALLARD and ADAMS 1969; WOLFE 1985; FINCKH and MUNDT 1993). In the present study, complementation seemed not to occur because growth in polyclonal plots was not increased compared with monoclonal plots. Furthermore, competition between plants in polyclonal plots may have induced a slight (but not significant) growth reduction of 'Boelare' and $P$. candicans plants compared with monoclonal plots of the same clones. In some cereal mixtures, compensation between plants induced increased yield (WHITE 1982; FINCKH and MUNDT 1992). However interactions between genotypes in mixtures of woody plants may result in diameter or height heterogeneity which may be a disadvantage for poplar growers and peeling industries (BISOFFI 1992; DEBELL and HARRINGTON 1997).

Disease can also act directly or indirectly on plant growth or yield (ALEXANDER et al. 1986; FINCKH and MUNDT 1992). In our field trial, Melampsora infection in 1997 influenced growth in 1998. Plants severely attacked in 1997 had a slower growth in 1998. SPIERS (1976) has already described shoot and root growth reduction associated with infection caused by M. larici-populina. STEPIEN (1992) noted growth reduction due to physiological disorders caused by this foliar obligate pathogen. In short-rotation willow coppices, disease reduction during the first year of regrowth, caused much less growth reduction in polyclonal plots, especially during the second and third seasons of regrowth (MCCRACKEN and DAwSON 1994).

\subsection{Occurrence of a complex pathotype}

During the second year of vegetation a naturally occurring complex pathotype was described in the trial. This pathotype could not have arisen from recombination between pathotypes 1-3-4-5 and 3-4-7 inoculated in 1997 because larch, the alternate host is not present within $2 \mathrm{~km}$ from the trial field. Furthermore, the first infections within the trial occurred in midJuly whereas larch infection usually begins at the end of April with subsequent infection of poplars, present in the vicinity of the larches, at the end of May. This complex pathotype 1-3-4-5-7 was presumed to originate from a source outside the trial field, an experimental nursery $2.2 \mathrm{~km}$ away, where it was shown to be very frequent in 1998. Consequently, this pathotype modified the pathogen population considerably within the trial because it was able to infect two clones out of three. Nevertheless, this introduction rendered our trial quite similar to natural conditions. This complex pathotype was shown to be predominating in France, despite its high number of virulences. It was more frequent than other more simple pathotypes expressing also virulence 7 (PINON et al. 1998). Furthermore, a new complex pathotype, 1-2-3-4-5-7, that is able to infect all the commercial poplar clones has been detected on larch in Nancy during spring 1999 (PINON, unpublished results). This pathotype would be able to infect the three clones in our mixture trial. Even if this pathotype is still rare, its frequency could increase with the use of poplar mixture plantations, which could favour complex pathotypes. Their dissemination will be easy because poplar is often cultivated in open spaces and in large areas. The development of complex pathotypes able to infect many race-specific resistant poplar clones, could compromise the efficiency of poplar clone mixtures.

This project constitutes the first study on poplar clone mixtures and revealed that during 
two consecutive growing seasons, mixing poplar clones could induce a slight but significant reduction of rust infection. Nevertheless, this reduction seemed to be clone and year dependent. It may be partly due to the delay of infection on 'Boelare' plants in mixture and probably to cross protection. Reduction of infection in mixed plots was too low to result in a positive effect on growth. Further studies on poplar clone mixtures should be carried out on larger experimental trials and over a longer period in order to be more representative of actual poplar plantations. The number of poplar clones in the mixture may not be increased because of the small number of different race-specific types of resistance used in poplar cultivars. Infection by $M$. larici-populina in the trial should be initiated by natural infection as in the willow clone mixtures (MCCRACKEN and DAWSON 1994) given the difficulty of controlling an artificial rust infection. Identification of $M$. larici-populina pathotypes should be carried out during the experiment in order to detect the possible occurrence of complex pathotypes and to observe the evolution of the pathogen population. Nevertheless, poplar mixtures in areas where complex pathotypes are abundant may be of limited interest to control rust epidemics.

\section{Acknowledgements}

The authors would like to thank A. SChipfER, C. Husson and G. MARECHAL for their technical assistance, B. MARÇAIs and P. MONTPIED for statistical analysis, J. A. BROWNING for scientific information and A. NYs for reviewing the manuscript. The work reported forms part of a $\mathrm{PhD}$ thesis submitted to the University of Nancy by the first author and was supported by a grant from the 'Ministère de l'Education Nationale, de la Recherche et de la Technologie' and from the 'Ministère de l'Agriculture' (CTPS).

\section{Résumé}

Mélange variétal de clones de peuplier: effets sur l'infection par Melampsora larici-populina et sur la croissance des plants

Les effets d'un mélange de clones de peuplier sur le taux d'infection causé par Melampsora laricipopulina et sur la croissance des plants ont été étudiés durant deux années consécutives. Le mélange variétal consiste en un mélange pied à pied de trois clones de peuplier, Populus $x$ interamericana 'Boelare', 'Rap' and Populus candicans 'NNT' exprimant des résistances race-spécifique différentes. Le taux d'infection a été estimé dans les parcelles monoclonales et polyclonales. La hauteur des plants a été mesurée à la fin de chaque saison de végétation. A la fin de la première année de végétation, le taux d'infection entre les parcelles monoclonales et polyclonales n'était pas significativement différent. Au cours de la deuxième saison de végétation, un pathotype complexe de $M$. larici-populina, capable d'infecter 'Boelare' et 'Rap', a envahi prématurément certaines parcelles de l'essai. Ce pathotype a modifié la composition de la population pathogène. Au cours de cette saison de végétation quatre notations d'infection ont été effectuées. La moyenne du taux d'infection des plants de 'Boelare' et de $P$. candicans dans les parcelles polyclonales était inférieure à la moyenne du taux d'infection dans les parcelles monoclonales. Néanmoins, aucune différence significative de croissance des plants n'a été observée entre les parcelles monoclonales et polyclonales. Les facteurs biologiques pouvant être impliqués dans la diminution du taux d'infection dans les parcelles polyclonales sont la dilution des individus sensibles, la barrière physique causée par les plants résistants et la prémunition. Un taux d'auto-infection élevé a vraisemblablement masqué en partie les effets positifs du mélange variétal.

\section{Zusammenfassung}

Sortenmischung von Pappelklonen: Auswirkungen auf die Infektion mit Melampsora larici-populina und auf das Pflanzenwachstum

Während zweier aufeinanderfolgenden Vegetationsperioden wurden die Auswirkungen einer Sortenmischung bei Pappeln auf das Ausmass der Infektion mit Melampsora larici-populina und das Pflanzenwachstum untersucht. Die Sortenmischung bestand aus den drei direkt nebeneinander gepflanzten Pappelklonen Populus $\times$ interamericana 'Boelare', 'Rap' und Populus candicans 'NNT' mit unterschiedlichen rassenspezifischen Resistenzen. Das Ausmass der Infektion wurde in monoklonalen und 
polyklonalen Pflanzungen verglichen. Am Ende jeder Vegetationsperiode wurde die Pflanzenhöhe bestimmt. Am Ende des ersten Jahres war die Infektionsrate zwischen mono- und polyklonalen Pflanzungen nicht signifikant verschieden. Während der zweiten Vegetationsperiode befiel ein natürlich vorkommender komplexer Pathotyp, der die Klone 'Boelare' und 'Rap' infizieren konnte, vorzeitig einige Versuchsflächen und änderte damit die Zusammensetzung der Pathogenpopulation. In dieser Saison wurde der Grad der Infektion viermal erfasst. Für die Sorten 'Boelare' und $P$. candicans 'NNT' wurde bei den polyklonalen Flächen im Vergleich zu den monoklonalen eine Reduktion der Infektion beobachtet. Trotzdem ergaben sich keine signifikanten Wachstumsunterschiede zwischen den monound polyklonalen Pflanzungen. Folgende biologische Faktoren können bei der Reduktion der Infektion in polyklonalen Pflanzungen eine Rolle spielen: Verringerung der Anzahl anfälliger Individuen, eine durch resistente Pflanzen gebildete physische Barriere und cross-protection. Eine hohe Selbstinfektionsrate dürfte die positiven Effekte einer Klonmischung teilweise verdeckt haben.

\section{References}

AKANDA, S. I.; MUNDT, C. C., 1996: Effects of two-component wheat cultivar mixtures on stripe rust severity. Phytopathology 86, 347-353.

Alexander, H. M.; Roelfs, A. P.; CoBbs, G., 1986: Effects of disease and plant competition on yield in monocultures and mixtures of two wheat cultivars. Plant Pathol. 35, 457-465.

Allard, R. W.; ADAMS, J., 1969: Population studies in predominantly self-pollinating species. XIII. Intergenotypic competition and population structure in barley and wheat. Am. Nat. 103, 621-645.

BERGER, R. D., 1972: Infection rates of Cercospora apii in mixed populations of susceptible and tolerant celery. Phytopathology 63, 535-537.

BlAise, P. H.; GESSLER, C., 1994: Cultivar mixtures in apple orchards as a mean to control apple scab? Norweg. J. Agric. Sci. 17, 105-112.

BISOFFI, S., 1992: Multiclonal poplar plantations: mixtures vs mosaics. In: Poplar and Willow Growing in Combination with Agriculture. Proceedings of the 19th Session Int. Poplar Commission, Zaragoza, Spain, September 22-25. Ed. by PADRO, A. Salamanca: Edición Técnica de Congresos. pp. 496-504.

BURDON, J. J., 1978: Mechanisms of disease control in heterogeneous plant populations - an ecologist's view. In: Plant Disease Epidemiology. Ed. by SCOTT, P. R.; BAINBRIDGE, A. Oxford: Blackwells. pp. 193-200.

Calonnec, A.; Goyeau, H.; De Vallavieille-Pope, C., 1996: Effects of induced resistance on infection efficiency and sporulation of Puccinia striiformis on seedlings in varietal mixtures and on field epidemics in pure stands. Eur. J. Plant Path. 102, 733-741.

ChIn, K. M.; Wolfe, M. S., 1984: Selection on Erysiphe graminis in pure and mixed stands of barley. Plant Pathol. 33, 535-546.

DeBell, D. S.; Harrington, C. A., 1997: Productivity of Populus in monoclonal and polyclonal blocks at three spacings. Can. J. For. Res. 27, 978-985.

FINCKH, M. R.; MUNDT, C. C., 1992: Stripe rust, yield, and plant competition in wheat cultivar mixtures. Phytopathology 82, 905-913.

FINCKH, M. R.; MUNDT, C. C., 1993: Effects of stripe rust on the evolution of genetically diverse wheat populations. Theor. Appl. Genet. 85, 809-821.

HeYbroeK, H. M., 1978: Importance de la multiplication et de la diversité génétique. Unasylva 30, 2733.

Heybroek, H. M., 1982a: The right tree in the right place. Unasylva 34, 15-19.

HeybroeK, H. M., 1982b: Monoculture versus mixture: interactions between susceptible and resistant trees in a mixed stand. In: Resistance to Diseases and Pests in Forest Trees. Proceedings of the 3rd Int. Workshop on the Genetics of Host-Parasite Interactions in Forestry, Wageningen, Netherlands, May 14-21, 1980. Ed. by Heybroek, H. M.; Stephan, B. R.; Von WeissenberG, K. Wageningen: Centre for Agricultural Publishing \& Documentation. pp. 326-341.

JENSEN, N. F., 1952: Intra-varietal diversification in oat breeding. Agro. J. 44, 30-34.

JoAnNES, H.; PINON, J., 1982: Comparaison de deux méthodes d'estimation de l'infection de jeunes peupliers par le Marssonina brunnea (Ell. Et Ev.) P. Magn. Eur. J. For. Path. 12, 87-96.

JOHNSON, R.; AllEN, D. J., 1975: Induced resistance to rust disease and its possible role in the resistance of multiline varieties. Ann. Appl. Biol. 80, 359-363.

DE KAM, M., 1983: Het afsterven van populieren in 1982. Populier. 20, 6-8.

LANNOU, C.; MUNDT, C. C., 1996: Evolution of a pathogen population in host mixtures: simple racecomplex race competition. Plant Pathol. 45, 440-453.

LEONARD, K. J., 1969: Factors affecting rates of stem rust increase in mixed plantings of susceptible and resistant oat varieties. Phytopathology 59, 1845-1850.

MCCRACKEN, A. R.; DAWSON, W. M., 1994: Experiences in the use of mixed-clonal stands of Salix as a method of reducing the impact of rust diseases. Norweg. J. Agric. Sci. 18, 101-109. 
MCCracken, A. R.; Dawson, W. M., 1997: Growing clonal mixtures of willow to reduce effect of Melampsora epitea var. epitea. Eur. J. For. Path. 27, 319-329.

Mahmood, T.; Marshall, D.; MCDANiEl, M. E., 1991: Effect of winter cultivar mixtures on leaf rust severity and grain yield. Phytopathology $81,470-474$.

MiOT, S., 1999: Rôle de la variabilité de Melampsora larici-populina, agent de la rouille des peupliers, et de la structure de la population hôte sur l'évolution des populations de l'agent pathogène. $\mathrm{PhD}$ Thesis. France: University of Nancy.

MorenO-Ruiz, G.; CASTILlO-ZAPATA, J., 1990: The variety colombia: a variety of coffee with resistance to rust (Hemilia Vastatrix Berk. \& Br.). Technical Bull. 9, Chinchina, Caldas, Colombia: Cenicafé Publication. 27 pp.

MUNDT, C. C.; LEONARD, K. J., 1986: Analysis of factors affecting disease increase and spread in mixtures of immune and susceptible plants in computer-simulated epidemics. Phytopathology 76, $832-840$.

MundT, C. C.; LeONARD, K. J.; Kolar, S. C., 1996: Effect of genotype unit number and spatial arrangement on severity of yellow rust in wheat cultivar mixtures. Plant Pathol. 45, 215-222.

PARKER, S. R.; ARNOld, G. M.; ROYLE, D. J., 1996: Plantation designs for short rotation coppice that will stand the test of time. Aspects App. Biol. 46, 239-246.

PINON, J., 1995: Variabilité des rouilles du peuplier et évolution de leurs populations. Conséquences sur les stratégies de lutte. C. R. Acad. Agric. Fr. 81, 99-109.

PinOn, J.; VAn Dam, B. C.; GeneTeT, I.; DE KAM, M., 1987: Two pathogenic races of Melampsora larici-populina in north-western Europe. Eur. J. For. Path. 17, 47-53.

PinON, J.; FreY, P., 1997: Structure of Melampsora larici-populina populations on wild and cultivated poplar. Eur. J. Plant Pathol. 103, 159-173.

PINON, J.; FREY, P.; HUSSON, C.; SCHIPFER, A., 1998: Poplar rust (Melampsora larici-populina): the development of E4 pathotypes in France since 1994. In: Proc. First IUFRO Rusts of Forest Trees WP Conference, Saariselkä, Finland, 2-7 August, 1998. Ed. by Jalkanen, R.; Crane, P. P. E.; WALLA, J. J. A.; AALTO, T.; Finland: The Finish Forest Research Institute, Research papers 712, 5764

SAlES, C., 1995: Le peuplier dans la filière bois. C. R. Acad. Agric. Fr. 81, 15-22.

SAS INSTITUTE INC., 1989: SAS/STAT User's guide, Version 6, Vol. 2. Cary, NC: SAS Institute Inc. SERVICE CENTRAL DES ENQUÊTES ET ETUdES STATISTIQUES, 1996: La forêt et les industries du bois. Paris, France: AGRESTE.

SCHREINER, E. J., 1966: Future needs for maximum progress in genetic improvement of disease resistance in forest trees. In: Breeding for Pest Resistance in Trees. Proc. Of NATO and NSF Advanced Study Institute on Genetic Improvement for Disease and Insect Resistance of Forest Trees, Pennsylvannia State University, University Park, Pennsylvania, August 30-September 11, 1964. Ed. by Gerhold, H. D.; Schreiner, E. J.; MCDERMOTT, R. E.; WinSESKI, J. A. New York: Pergamon Press. pp. 455-466.

SPIERS, A. G., 1976: Fungicides for control of poplar leaf rust and effects of control on growth of Populus nigra cv 'Sempervirens' and $P$. x euramericana Cv. 'I214'. New Zeal. J. Exp. Agric. 4, 249254.

STEPIEN, V., 1992: Contribution à l'étude des protéines de réserve végétatives du peuplier (Populus x euramericana). PhD Thesis. France: University of Nancy.

TerRasson, D.; VALADON, A., 1993: Conseils préliminaires pour l'utilisation des clones de peupliers inscrits sur les catalogues des Etats membres de la CEE. Informations techniques du Cemagref 92. 7 pp.

VIART, M., 1998: Culture des peupliers et biodiversité. C. R. Acad. Agric. Fr. 84, 155-166.

WHITE, E. M., 1982: The effects of mixing barley cultivars on incidence of powdery mildew (Erysiphe graminis) and on yield in Northern Ireland. Annu. Appl. Biol. 101, 539-545.

WOLFE, M. S., 1985: The current status and prospects of multiline cultivars and variety mixtures for disease resistance. Annu. Rev. Phytopathol. 23, 251-273.

WOLFE, M. S.; BARRETT, J. A.; JENKINS, J. E. E., 1981: The use of cultivar mixtures for disease control. In: Strategies for the Control. of Cereal Disease. Ed. by Jenkyn, J. F.; Plumb, R. T. Oxford: Blackwells. pp. 73-80. 